\title{
ANALISIS WACANA KRITIS TERHADAP NASKAH PUBLIKASI \\ PIDATO KENEGARAAN PRESIDEN JOKO WIDODO \\ DALAM RANGKA HUT KE-70 PROKLAMASI KEMERDEKAAN REPUBLIK INDONESIA
}

\author{
Oleh: \\ Dermawati Mahmuda Nur \\ (Pendidikan Bahasa dan Sastra Indonesia, Fakultas Keguruan dan Ilmu Pendidikan, Universitas PGRI Adi Buana \\ Surabaya) \\ wnurma27mn@gmail.com
}

Sunu Catur Budiono

(Dosen Program Studi Pendidikan Bahasa dan Sastra Indonesia, Fakultas Keguruan dan Ilmu Pendidikan, Universitas PGRI Adi Buana Surabaya)

sunucatur85@gmail.com

\begin{abstract}
Using language into the published manuscript of state speech of President Joko Widodo tended to not transparent, but contained of much meaning of rhetoric. So that, critical discourse analysis (CDA) was chosen as an instrument for questioning some interests, values or instructions which were hidden behind of the language. This research aimed to describe text structure, social cognition, and social context about published manuscript of state speech of President Joko Widodo for 70rd anniversary of The Republic of Indonesia. Researcher used a qualitative approach for discourse analysis within theory of Teun A. van Dijk. Result of this research was text structure about this published manuscript speech which included of 3 sections, which were: macrostructure, superstructure and microstructure. About the macrostructure, the research focus was about its topic. About the superstructure, the research focus was its schema or its plot. While the microstructure, the observational focus were its semantic, syntactic, and stylistic aspects. About the social cognition of this manuscript, it included 3 schemas or models, which were: person schemas, role schemas, and event schemas. Meanwhile, about the social context of this published manuscript of President Joko Widodo's state speech, it included of practice of power and also access which controlled over the discourse.
\end{abstract}

Keywords: Published Manuscript, Critical Discourse Analysis, State Speech.

\section{PENDAHULUAN}

Sebuah naskah pidato tercipta berdasarkan penggarapan yang sangat cermat dan teliti, dengan sumbangan pikiran dari berbagai pihak, atas dasar pertimbangan yang matang dengan penyimakan berkalikali (Teeuw, 1994: 19). Namun dewasa ini, sebagian besar pidato hanyalah sebatas wacana. Darma (2014: 1) berpendapat bahwa wacana berasal dari bahasa Latin, yaitu discursus. Istilah ini secara khusus menunjuk pada aturan-aturan dan kebiasaankebiasaan yang mendasari penggunaan bahasa baik dalam komunikasi lisan maupun tulisan. Adapun istilah tersebut yang secara luas, yaitu wacana menunjuk pada bahasa dalam tindakan serta pola-pola yang menjadi ciri jenis-jenis bahasa dalam tindakan.

Wacana adalah praksis sosial dalam bentuk interaksi simbolis yang bisa terungkap dalam pembicaraan, tulisan, kial, gambar, diagram, film atau musik (N. Fairclough, 2010: 233; dan M. Bloor \& Thomas, 2007: 1-2, dalam Haryatmoko, 2017: 3). Sedangkan menurut Badudu (2000) (dalam Darma, 2014: 2) bahwa wacana sebagai rentetan kalimat yang 
berkaitan dengan yang menghubungkan proposisi yang satu dengan proposisi yang lainnya, membentuk satu kesatuan, sehingga terbentuklah makna yang serasi di antara kalimat-kalimat itu. Selanjutnya dijelaskan pula bahwa wacana merupakan kesatuan bahasa terlengkap dan tertinggi atau terbesar di atas kalimat atau klausa dengan koherensi dan kohesi yang tinggi yang berkesinambungan, yang mampu mempunyai awal dan akhir yang nyata, disampaikan secara lisan dan tertulis.

Berdasarkan pengertian wacana di atas, peneliti mengambil simpulan bahwa wacana adalah interaksi simbolis yang berupa untuk mempresentasikan pengetahuan tentang topik khusus pada periode tertentu.

Sebuah analisis wacana di dalamnya selalu membahas ideologi. Menurut Eriyanto (2011: 3) dalam lapangan politik, analisis wacana merupakan praktik pemakaian bahasa, terutama politik bahasa karena bahasa adalah aspek sentral dari penggambaran suatu subjek, dan lewat bahasa ideologi terserap di dalamnya. Ideologi merupakan sebuah konsep yang fundamental dan aktual dalam sebuah negara. Setiap penggunaan bahasa yang bertujuan sebagai konsumsi publik harus disikapi penanaman sebuah ideologi tertentu.

Ideologi berasal dari bahasa Greek, yang terdiri atas kata idea dan logic. Idea berasal dari kata idein yang berarti melihat. Idea dalam Webster's New Colligiate Dictionary berarti "something existing in the mind as the result of the formulation of an opinion, a plan or the like" (sesuatu yang ada di dalam pikiran sebagai hasil perumusan sesuatu pemikiran atau rencana). Logic berasal dari kata logos yang berarti word. Kata logic berasal dari kata legein yang berarti to speak (berbicara). Selanjutnya kata logic berarti science (pengetahuan) atau teori. Jadi, ideologi menurut arti kata ialah pengucapan dari yang terlihat atau pengutaraan apa yang terumus di dalam pikir sebagai hasil dari pemikiran (Sukarna, 1981: 1 dalam Darma, 2014:179). Sedangkan menurut Raymond William (dalam Eriyanto, 2006: 88; Darma, 2014: 180) merumuskan ideologi ke dalam tiga ranah, yaitu yang pertama adalah sebuah sistem kepercayaan yang dimiliki oleh kelompok atau kelas tertentu; yang kedua adalah sebuah sistem kepercayaan yang dibuat - ide palsu atau kesadaran palsu; dan yang ketiga adalah proses umum produksi makna dan ide.

Ada dua pengertian ideologi dalam masyarakat menurut Ramlan Surbakti (1992) pertama yaitu ideologi secara fungsional yang diartikan tentang masyarakat dan negara yang diangap paling baik atau demi kebaikan bersama. Kedua yaitu ideologi secara struktural diartikan sebagai pembenaran atas setiap kebijakan dan tindakan yang diambil oleh penguasa seperti gagasan dan formula politik (Darma, 2014: 181).

Dengan demikian, peneliti mengambil simpulan bahwa ideologi merupakan alat pengikat yang baik karena didasarkan pada pemikiran yang menyatakan, jika persatuan sudah terwujud maka alat pengikat sudah tidak diperlukan. Kenyataan menunjukkan bahwa kebersamaan masyarakat sebenarnya dibangun diatas keanekaragamaan (budaya, etnis, bahasa, agama dan sebagainya), sehingga perpecahan merupakan benih yang subur dan siap meledak setiap saat.

Seluruh aktivitas dan pemaknaan simbolik dapat dilakukan dalam teks media massa atau naskah publikasi. Pada dasarnya, naskah publikasi bukan realitas yang bebas nilai. Pada titik kesadaran pokok manusia, teks selalu memuat kepentingan. Teks pada prinsipnya telah diambil sebagai realitas yang memihak. Tentu saja teks dimanfaatkan untuk memenangkan pertarungan ide, kepentingan atau ideologi tertentu kelas tertentu. Pada titik tertentu, naskah publikasi pada dirinya sudah bersifat ideologis (Littlejhon, 2002: 217 ; Darma, 2014: 166). Seperti halnya pada naskah 
publikasi pidato Presiden Joko Widodo yang akan peneliti teliti.

Judul skripsi yang dipilih peneliti untuk diteliti adalah "Analisis Wacana Kritis Terhadap Naskah Publikasi Pidato Kenegaraan Presiden Joko Widodo dalam Rangka HUT Ke-70 Proklamasi Kemerdekaan Republik Indonesia”. Naskah pidato tesebut dipublikasikan oleh Sekretariat Kabinet Republik Indonesia melalui website resmi kenegaraan www.//setkab.go.id/.

Dari pemaparan di atas, hal itulah yang menarik untuk peneliti kaji. Analisis wacana adalah penelitian yang bersifat kualitatif. Analisis wacana digunakan untuk membongkar kuasa yang ada dalam setiap proses bahasa; perspektif yang mesti dipakai; topik apa yang dibicarakan; dan struktur yang terkandung dalam bahasa (penggunaan dari bahasa itu sendiri) yang biasa digunakan untuk meneliti pesan tulisan. Dan pada umumnya adalah mengungkapkan gagasan yang dimiliki oleh objek penelitian.

Penggunaan bahasa dalam naskah publikasi pidato Presiden Joko Widodo cenderung tidak transparan, artinya banyak wacana tidak mengungkapkan maksud tulus pewicara atau penulis, tapi sarat dengan retorika, manipulasi, dan penyesatan. Maka, sikap kritis yang menjadikan penelitian peneliti menjadi analisis wacana kritis, perlu untuk mempertanyakan dan mencurigai adanya, nilai atau petunjuk yang disembunyikan dibalik bahasa.

Peneliti menggunakan metode analisis wacana kritis juga untuk mengungkap ideologi yang ada dalam naskah publikasi pidato Presiden Joko Widodo. Narendra (2008: 140) juga mengungkapkan bahwa tujuan dari analisis wacana kritis adalah mengkritisi ideologi yang melatarbelakangi sebuah wacana dengan jalan menelanjangi asumsi-asumsi kebenaran yang sering kali sudah menjadi pemikiran umum dalam masyarakat.
Dengan demikian, penelitian ini diharapkan dapat menelanjangi penggunaan bahasa yang berkaitan dengan ideologi Presiden Joko Widodo, retorika, penggunaan perbendaharaan kata, istilah atau metafora sudah mengarah ke makna tertentu; tata bahasa mengatur penggunaan kata kerja, tema, modalitas; koherensi atau keterpaduan kalimat; dan struktur teks mencerminkan logika argumen untuk pembenaran yang berada dibalik terbitnya naskah publikasi pidato kenegaraan Presiden Joko Widodo dalam Rangka HUT Ke-70 Proklamasi Kemerdekaan Republik Indonesia.

\section{METODE PENELITIAN}

Metode yang digunakan dalam penelitian ini adalah metode analisis deskriptif. Metode ini dilakukan dengan cara menganalisis informasi yang memiliki aktualitas yang cukup tinggi. Penelitian ini menggunakan pendekatan analisis teks, khususnya analisis wacana kritis. Analisis ini memusatkan analisis wacana pada bahasa yang dikritisi dan menghubungkannya dengan ideologi.

Data yang peneliti ambil untuk penelitian ini berupa transkrip pidato yang telah dipublikasikan melalui internet. Dan sumber data yang digunakan adalah situs website yang terpercaya, yakni www.setkab.go.id.

Dalam pengumpulan data, peneliti mencari data berupa naskah publikasi pidato kenegaraan Presiden Joko Widodo dalam rangka HUT ke -70 proklamasi kemerdekaan Republik Indonesia di internet. Yang kemudian dibaca dan dipahami secara detil isi naskah publikasi pidato tersebut. Kemudian, dikaitkan dengan teori-teori yang tepat yang dapat digunakan dalam menganalisis naskah publikasi pidato tersebut. Dan selanjutnya adalah, dengan mengelompokkan data-data berdasarkan teori yang telah dipilih.

Teknik-teknik yang dipilih peneliti dalam penelitian ini adalah dengan cara 
menginterpretasikan data berdasarkan teori van Dijk. Selanjutnya adalah mengeksplanasi data dengan teori tersebut. Kemudian, mendeskripsikan data yang telah dikumpulkan dan diberi penjelasan sebab akibat mengapa disebut langsung demikian. Langkah yang terakhir adalah menympulkan.

\section{HASIL DAN PEMBAHASAN}

Data dalam penelitian ini adalah analisis dari segi struktur teks, kognisi sosial, dan konteks sosial atau analisis sosial.

1) Struktur teks, terdiri dari:

a) Struktur makro (tematik)

Topik dalam naskah publikasi pidato kenegaraan Presiden Joko Widodo dalam rangka HUT ke-70 proklamasi kemerdekaan Republik Indonesia yang bertema "Menjadikan bangsa Indonesia menjadi Nawacita melalui gerakan nasional revolusi mental, sesuai dengan gagasan yang telah dijadikan acuan oleh Presiden Joko Widodo, dan juga diungkapkan sebagai semangat kepada rakyat saat menyampaikan pidato kenegaraan pertamanya sebagai presiden Republik Indonesia."

Langkah awal dalam menjalankan "Gerakan Nasional Revolusi Mental" adalah salam yang terdiri dari 4 perspektif beragama. Kemudian, dilanjutkan dengan memaparkan hal-hal yang termasuk dalam visi Nawacita yang telah digagas oleh Presiden Joko Widodo. Visi nawacita tersebut, diantaranya: 1) Pembangunan yang bersifat konsumtif menjadi produktif, demi menjaga kepentingan nasional. Pembangunan tersebut dimulai dari pinggiran, dari daerah dan desa-desa; 2) Menjaga APBN agar tetap sehat, berkualitas, dan berkelanjutan; 3) Pembangunan infrastruktur; 4) Mewujudkan kemandirian ekonomi dengan memperbanyak pasar rakyat; 5) Melakukan revolusi karakter bangsa dengan membuat aksi pembangunan yang dikelola dan diinovasi oleh anak bangsa sendiri; 6) Melakukan transformasi ekonomi sebagai daya saing di pasar Internasional; 7) Memperteguh kebhineka-an dengan memberdayakan alutsista produksi dalam negeri; 8) Membentuk badan penegak hukum, dan; 9) Melindungi negara Indonesia dengan cara melindungi masyarakat adat dalam menghadapi konflik Agraria.

b) Superstruktur (skema)

Tidak berbeda jauh dari topik, skema juga berkaitan dengan visi Nawacita yang digagas oleh Presiden Joko Widodo. Skema/alur terbagi menjadi dua bagian besar. Yang pertama yaitu summary dan lead. Yang kedua yaitu story. Summary ditandai dengan judul pidato, judulnya adalah "Pidato Kenegaraan Presiden Republik Indonesia dalam Rangka HUT ke -70 Proklamasi Republik Indonesia, di depan Sidang bersama DPR RI dan DPD RI, Jakarta, 14 Agustus 2015." Lead sebagai pengantar ringkasan sebelum masuk dalam isi berita lengkap. Leadnya seperti kutipan di bawah ini,

"Saudara-saudara se-Bangsa dan se-Tanah Air,

Hadirin sekalian yang saya muliakan. Marilah kita bersamasama bersyukur ke hadirat Allah SWT, Tuhan yang Maha Esa, karena atas karunia-Nya kita dapat menghadiri Sidang bersama Dewan Perwakilan Daerah dan Dewan Perwakilan Rakyat Republik Indonesia, dalam rangka Peringatan Proklamasi Kemerdekaan Republik Indonesia yang ke-70.” (Pr 3: 1)

"Hari ini di depan sidang yang terhormat, saya akan menyampaikan Pidato Kenegaraan 
pertama saya sebagai Presiden Republik Indonesia.” (Pr 4: 2)

Yang kedua, dilanjutkan dengan story atau berita keseluruhan yang terdapat dalam naskah publikasi pidato kenegaraan Presiden Joko Widodo dalam rangka HUT ke-70 proklamasi kemerdekaan Republik Indonesia. Story atau berita yang dipaparkan berkaitan dengan visi Nawacita yang digagas oleh Presiden Joko Widodo.

c) Struktur Mikro terbagi menjadi empat, yaitu semantik, sintaksis, stilistik, dan retoris. Semantik menjelaskan tentang makna yang ingin ditekankan, sintaksis menjelaskan tentang pendapat yang disampaikan, stilistik hanya terfokus pada leksikon atau pilihan kata yang dipakai, dan retoris menjelaskan tentang cara-cara yang dilakukan untuk penekanan. Stuktur-struktur tersebut terdapat dalam naskah publikasi pidato kenegaraan Presiden Joko Widodo.

2) Kognisi sosial yang merupakan pikiran dan kesadaran dalam membentuk suatu teks, terdiri dari skema person (Person Schemas), skema peran (Role Schemas), dan skema peristiwa (Event Schemas). Berdasarkan naskah publikasi pidato Presiden Joko Widodo, yang membuat peneliti menyimpulkan sebagai skema personnya adalah sebagai berikut.

"Hari ini di depan sidang yang terhormat, saya akan menyampaikan

Pidato Kenegaraan pertama saya sebagai Presiden Republik Indonesia." (Pr 4: 2)

"Kita membutuhkan lebih banyak lagi pejuang pembangunan seperti Saudara-saudara, yang menjunjung nilai-nilai integritas, etos kerja, dan semangat gotong royong. Untuk itu, pada hari ini saya menegaskan kembali perlunya gerakan nasional revolusi mental. Gerakan tersebut akan menyuburkan kembali nilainilai semangat juang, optimisme, kerja keras, kesantunan, tatakrama, dan memperkokoh karakter bangsa, serta memperkuat tatanan kehidupan berbangsa dan bernegara berdasarkan Pancasila dan UUD 1945." (Pr 58: 10)

Dari uraian di atas, terdapat sebuah kesadaran bahwa teks pidato Presiden Joko Widodo berawal dari pidato kali pertama atas kepemimpinannya. Presiden sebagai komunikator mengajak anggota dewan agar berjuang untuk pembangunan. Beliau juga menekankan bahwa perlunya Gerakan Nasional Revolusi Mental yang menurutnya gerakan tersebut menumbuhkan kembali nilai-nilai semangat juang, optimisme, kerja keras, kesantunan, tatakrama, dan memperkokoh karakter bangsa yang dulunya pernah dimiliki serta menjadi ciri khas dari bangsa Indonesia, dan juga berfungsi sebagai landasan untuk memperkuat tatanan kehidupan berbangsa dan bernegara yang didasarkan Pancasila dan UUD 1945.

"Sebagai ilustrasi, tahun 2014, sekitar 240 triliun rupiah subsidi BBM hanya dibakar di jalan-jalan, hanya dibakar dan dinikmati oleh jutaan mobil pribadi; bukan dinikmati oleh masyarakat yang tinggal di gununggunung, di pesisir-pesisir, di pulaupulau terpencil, atau mereka yang hidup di bawah garis kemiskinan." (Pr 32: 6)

"Itulah yang saya sebut sebagai praktik yang tidak benar tersebut. Padahal uang sebesar itu dapat digunakan untuk membangun sekolah, membangun rumah sakit, meningkatkan kesejahteraan rakyat melalui program ekonomi produktif 
dan perlindungan sosial, serta membangun lebih banyak lagi infrastruktur.” (Pr 33: 6)

Paragraf di atas juga termasuk skema person, yang juga mengandung retorika yang sangat halus. Presiden Joko Widodo berupaya membandingkan dengan dirinya sendiri dan memberi contoh peristiwa nyata mengenai pemimpin nasional sebelumnya yang dianggapnya gagal. Dijelaskannya melalui penggambaran di tahun 2014, lebih kurang 240 triliun rupiah subsidi BBM yang seharusnya dapat dinikmati oleh masyarakat yang tinggal di gunung-gunung, di pesisirpesisir, di pulau terpencil, dan orang-orang yang hidup di bawah garis kemiskinan, namun diselewengkan. Dengan cara dibakar di jalan-jalan, dan dinikmati oleh jutaan mobil pribadi.

Skema yang kedua selanjutnya ialah skema peran (Role Schemas). Skema peran merupakan skema yang berhubungan dengan bagaimana seseorang memandang dan menggambarkan peranan dan posisi yang ditempati seseorang dalam masyarakat. Berikut paragrafnya.

\section{"Pemerintah tentu tidak hanya berpangku tangan. Dengan kemampuan yang ada, kita berikan bantuan dan pertolongan kepada warga yang tertimpa musibah. Kita berikan penghormatan dan penghargaan kepada para prajurit yang gugur akibat jatuhnya pesawat Hercules." (Pr 20: 4)}

Berdasarkan paragraf di atas, presiden menunjukkan sisi baik dari kemajuan pemerintah yang dinaungi oleh pemerintahannya. Paragraf di atas menjelaskan bahwa pemerintah ikut andil dalam membantu masyarakat yang tengah mengalami musibah. Dan memberikan penghargaan juga penghormatan kepada prajurit yang gugur saat menjalankan tugas.

\begin{abstract}
"Sejauh ini pemerintah senantiasa menjaga APBN tetap sehat, berkualitas, dan berkelanjutan. Kebijakan fiskal diarahkan untuk mendukung kemandirian fiskal melalui peningkatan penerimaan tanpa mengganggu iklim investasi. Kita kurangi ketergantungan pada penerimaan sumber daya alam. Kita kendalikan defisit anggaran dalam batas aman, dan kita jaga debt ratio, rasio hutang dalam batas yang terkendali. Selain itu, kita juga tata kembali sistem subsidi agar lebih tepat sasaran. Kita juga dorong pembangunan infrastruktur, ketahanan pangan, dan perlindungan sosial." (Pr 28: 5)
\end{abstract}

Selain itu, presiden juga menjelaskan mengenai kemajuan yang dilakukan oleh pemerintah, yakni dengan menjaga anggaran pembelanjaan negara dan mengendalikan anggaran serta membatasi hutang negara hingga dapat terkendali, mengontrol agar masyarakat dapat mengolah sumber daya alam hingga mereka tidak mengalami ketergantungan sebagai penerima saja. Halhal tersebut diupayakan untuk menopang perekonomian masyarakat di Indonesia. Di samping itu, pemerintah juga mendorong pembangunan infrastruktur, ketahanan pangan, dan perlindungan sosial.

Skema yang ketiga ialah skema peristiwa (Event Schemas). Skema ini paling sering banyak dipakai karena hal tersebut terkait dengan peristiwa sehari-hari yang (melihat, maupun mendengar) yang sangat mungkin untuk dimaknai dan ditafsirkan dalam skema tertentu. Berikut paragraf yang menunjukkan sebuah model peristiwa.

"Kita patut berterima kasih kepada para pendahulu kita, para pemimpin nasional, mulai dari Presiden Soekarno, Presiden Soeharto, Presiden B.J. Habibie, Presiden Abdurrahman Wahid, Presiden 
Megawati Soekarnoputri, dan Presiden Susilo Bambang Yudhoyono." (Pr 5: 2)

"Atas perjuangan dan kerja keras para pemimpin nasional tersebut, disertai dukungan sepenuh hati dari seluruh rakyat Indonesia, hari ini di saat kita memperingati 70 tahun Indonesia Merdeka, kita mempunyai modal yang lebih dari cukup untuk melompat maju." (Pr 6: 2)

Paragraf di atas merupakan pemahaman masyarakat tentang peristiwa yang lampau. Presiden Joko Widodo menyebutkan beberapa pemimpin nasional yang sangat berjasa untuk negara Indonesia sejak awal kemerdekaan hingga kemerdekaan yang ke-70 tahun. Pemimpinpemimpin nasional tersebut diantaranya, yaitu: 1) Presiden Soekarno sebagai Presiden Indonesia pertama; 2) Presiden Soeharto; 3 ) Presiden B.J. Habibie; 4) Presiden Abdurrahman Wahid; 5) Presiden Megawati Soekarnoputri; 6) Presiden Susilo Bambang Yudhoyono.

Presieden Joko Widodo menyadari bahwa para pemimpin nasional pun sejak dari dulu sudah membanting tulang dengan segenap jiwa dan raganya dalam membangun Negara Indonesia. Dukungan dari seluruh rakyat Indonesia juga, pembangunan Negara Indonesia agar menjadi negara maju perlahan-lahan yang semakin meningkat.

3) Konteks sosial atau analisis sosial dengan fokus utama ialah praktik kekuasaan akses mempengaruhi wacana. Kekuasaan berisi status dan pengetahuan, dan akses mempengaruhi wacana berisi tentang hal-hal yang belum tercapai maksimal pada pemerintahan sebelumnya dijadikan target, sering melakukan sorot balik tentang pemerintahan sebelumnya.

a) Praktik Kekuasaan
Menurut van Dijk (dalam Eriyanto: 272) kekuasaan umumnya didasarkan pada kepemilikan atas sumber-sumber yang bernilai, seperti uang, status, dan pengetahuan. Berikut kutipan paragraf yang termasuk dalam praktik kekuasaan Presiden Joko Widodo.

“.......... Sebagai bangsa yang besar, kita harus percaya diri, harus optimis, bahwa kita dapat mengatasi segala persoalan yang menghadang di hadapan kita." (Pr 10: 3)

Kata-kata yang termasuk dalam praktik kekuasaan diawali dengan kata 'harus', ia dituturkan sebanyak dua kali, pengulangan tersebut termasuk dalam penegasan. Kata 'harus' memiliki arti, yakni 'wajib'. Dalam kutipan di atas, terdapat kata 'optimis' dan kata 'percaya diri' yang bermakna membangun dan upaya yang diucapkan dalam memberikan motivasi untuk bangsa Indonesia.

Sebelum kata-kata tersebut, kata 'kita' juga diucapkan oleh komunikator. Kata 'kita' merupakan pronomina persona atau kata ganti orang. Kata 'kita' merupakan kata ganti orang pertama jamak, yang berbicara bersama dengan orang lain termasuk yang diajak bicara.

Berdasarkan penjelasan tersebut, kutipan di atas merupakan upaya komunikator untuk memasukkan praktik kekuasaannya dengan cara membuka mata bangsa Indonesia bahwa bangsanya adalah bangsa yang besar. Bangsa yang bukan hanya besar dalam tersebarnya penduduk di seluruh wilayah Indonesia, akan tetapi bangsa yang juga besar dalam hatinya. Yang dimaksudkan besar hati adalah sikap percaya diri dan jiwajiwa yang optimis. Hal tersebut sengaja dituturkan dengan tujuan untuk pemberian semangat kepada bangsa 
Indonesia bahwa mereka dapat mengatasi persoalan-persoalan yang telah ada.

Beliau juga menggunakan kata 'kita' sebagai kata ganti 'saya' yang menandakan kekuasaan. Tujuan penggunaan kata ganti 'kita' dalam kutipan di atas adalah agar pandangan masyarakat mengenai beliau sebagai petinggi di Negara Indonesia adalah pemimpin yang peduli dengan masyarakat, pemimpin yang turut serta membantu dan mengajak khalayak untuk mengatasi persoalan tersebut bersamasama.

b) Akses Mempengaruhi Wacana Analisis wacana Van Dijk memberi perhatian besar pada akses, akses di antara masing-masing kelompok dalam masyarakat. Dalam analisis ini, akses sangat digunakan untuk mengontrol pikiran khalayak. Akses yang lebih besar bukan hanya memberi kesempatan untuk mengontrol kesadaran khalayak, tetapi hal tersebut juga dapat digunakan untuk menentukan topik dan isi wacana yang dapat disebarkan dan didiskusikan kepada khalayak (Eriyanto, 2001: 272-274).

Apabila dilihat dari segi latar belakang komunikator terkait praktik kekuasaan, akses yang mempengaruhi wacana yang digunakan oleh komunikator adalah pencapaian pemerintahan sebelumnya sebagai tolok ukur yang dijadikan target perjalanan dalam pemerintahan selanjutnya.

"Kita patut berterima kasih kepada para pendahulu kita, para pemimpin nasional, mulai dari Presiden Soekarno, Presiden Soeharto, Presiden B.J. Habibie, Presiden Abdurrahman Wahid, Presiden Megawati Soekarnoputri, dan Presiden Susilo Bambang Yudhoyono." (Pr 5: 2)
"Atas perjuangan dan kerja keras para pemimpin nasional tersebut, disertai dukungan sepenuh hati dari seluruh rakyat Indonesia, hari ini di saat kita memperingati 70 tahun Indonesia Merdeka, kita mempunyai modal yang lebih dari cukup untuk melompat maju." (Pr 6: 2)

Kata 'kita' merupakan kata ganti orang (pronomina persona). Kata ganti 'kita' digunakan untuk menumbuhkan rasa solidaritas. Selanjutnya, ada kata 'patut' yang berarti 'pantas'. Dan, kata 'berterima kasih' merupakan kata turunan dari prefiks ber- dan kata 'terima kasih'. Kata 'terima kasih' berarti melahirkan rasa syukur atau membalas budi setelah menerima kebaikan dan sebagainya.

Berdasarkan penjelasan tersebut, paragraf di atas menjelaskan tentang akses komunikator untuk mempengaruhi wacana melalui kilas balik tentang perjuangan para pemimpin nasional sebelumnya, dan sekaligus mengucap rasa syukur kepada mereka yang telah berjasa.

Rasa terima kasih terucap atas perjuangan para pemimpin nasional para pendahulu, para presiden sebelumnya, yakni Presiden Soekarno, Presiden Soeharto, Presiden B.J. Habibie, Presiden Abdurrahman Wahid, Presiden Megawati Soekarnoputri, dan Presiden Susilo Bambang Yudhoyono, serta dukungan dari seluruh rakyat dengan sepenuh hati. Karena perjuangan dan kerja keras mereka bangsa Indonesia dapat merdeka hingga 70 tahun merdeka.

\section{SIMPULAN}

Struktur teks dalam analisis wacana kritis terhadap naskah publikasi pidato kenegaraan Presiden Joko Widodo dalam rangka HUT ke-70 proklamasi kemerdekaan 
Republik Indonesia meliputi tiga bagian yaitu struktur makro, superstruktur, dan struktur mikro. Struktur mikro ini fokus pengamatannya adalah semantik, sintaksis, stilistik, dan retoris.

Kognisi sosial dalam analisis wacana kritis terhadap naskah publikasi pidato kenegaraan Presiden Joko Widodo dalam rangka HUT ke-70 proklamasi kemerdekaan Republik Indonesia meliputi tiga skema/model yaitu skema person (Person Schemas), skema peran (Role Schemas), dan skema peristiwa (Event Schemas).

Konteks sosial atau analisis sosial dalam analisis wacana kritis terhadap naskah publikasi pidato kenegaraan Presiden Joko Widodo dalam rangka HUT ke-70 proklamasi kemerdekaan Republik Indonesia mencakup praktik kekuasaan dan akses mempengaruhi wacana.

\section{DAFTAR PUSTAKA}

Darma, Yoce Aliah. 2014. Analisis Wacana Kritis dalam Multiperspektif. Bandung: PT. Refika Aditama.

Eriyanto. 2001. Analisis Wacana:

Pengantar Analisis Teks Media.

Yogyakarta: LKiS.

Haryatmoko. 2017. Critical Discourse Analysis (Analisis Wacana Kritis):

Landasan Teori, Metodologi, dan Penerapan. Jakarta: Rajawali Perss.

Narendra, Pitra. 2008. Metodologi Riset Komunikasi: Panduan untuk Melaksanakan Penelitian Komunikasi. Yogyakarta: Balai Pengkajian dan Pengembangan Informasi (BPPI) IV Yogyakarta dan Pusat Kajian Media dan Budaya Populer (PKMBP).

Teeuw, A. 1994. Indonesia Antara Kelisanan dan Keberaksaraan. Jakarta: Pustaka Jaya.

www.setkab.go.id. Diakses pada tangal 12 Februari 2018, pukul 17.00 WIB.

http://setkab.go.id/pidato-kenegaraanPresiden-republik-indonesia-dalam- rangka-hut-ke-70-proklamasikemerdekaan-republik-indonesia-didepan-sidang-bersama-dpr-ri-dandpd-ri-jakarta-14-agustus-2015/. Diakses pada tangal 12 Februari 2018, pukul 17.00 WIB. 